\title{
Scenarios of land-use change in a deforestation corridor in the Brazilian Amazon: combining two scales of analysis
}

\author{
Florian Gollnow $^{1}$ (1) Jan Göpel ${ }^{2}$ Letícia deBarros Viana Hissa ${ }^{1,3} \cdot$ \\ Rüdiger Schaldach $^{2} \cdot$ Tobia Lakes $^{1,3}$
}

Received: 21 December 2015/ Accepted: 13 February 2017/Published online: 2 March 2017

(C) The Author(s) 2017. This article is published with open access at Springerlink.com

\begin{abstract}
Local, regional, and global processes affect deforestation and land-use changes in the Brazilian Amazon. Characteristics are: direct conversions from forest to pasture; regional processes of indirect land-use change, described by the conversion of pastures to cropland, which increases the demand for pastures elsewhere; and teleconnections, fueled by the global demands for soybeans as animal fodder. We modeled land-use changes for two scenarios Trend and Sustainable Development for a hot spot of land-use change along the BR-163 highway in Mato Grosso and Pará, Brazil. We investigated the differences between a coupled modeling approach, which incorporates
\end{abstract}

Electronic supplementary material The online version of this article (doi:10.1007/s10113-017-1129-1) contains supplementary material, which is available to authorized users.

Florian Gollnow

florian.gollnow@geo.hu-berlin.de;

florian.gollnow@outlook.com

Jan Göpel

goepel@cesr.de

Letícia deBarros Viana Hissa

leticia.hissa@geo.hu-berlin.de

Rüdiger Schaldach

schaldach@usf.uni-kassel.de

Tobia Lakes

tobia.lakes@geo.hu-berlin.de

1 Department of Geography, Humboldt-Universität zu Berlin, Unter den Linden 6, 10099 Berlin, Germany

2 Center for Environmental System Research, Universität Kassel, Wilhelmshöher Allee 47, 34117 Kassel, Germany

3 Integrative Research Institute on Transformations of HumanEnvironment Systems, Humboldt-Universität zu Berlin, Unter den Linden 6, 10099 Berlin, Germany indirect land-use change processes, and a noncoupled landuse model. We coupled the regional-scale LandSHIFT model, defined for Mato Grosso and Pará, with a subregional model, alucR, covering a selected corridor along the BR-163. The results indicated distinct land-use scenario outcomes from the coupled modeling approach and the subregional model quantification. We found the highest deforestation estimates returned from the subregional quantification of the Trend scenario. This originated from the strong local dynamics of past deforestation and landuse changes. Land-use changes exceeded the demands estimated at regional scale. We observed the lowest deforestation estimates at the subregional quantification of the Sustainable Development story line. We highlight that model coupling increased the representation of scenario outcomes at fine resolution while providing consistency across scales. However, distinct local dynamics were explicitly captured at subregional scale. The scenario result pinpoints the importance of policies to aim at the cattle ranching sector, to increase land tenure registration and enforcement of environmental laws.

Keywords Land-use modeling - Multiscale · Cross-scale · Brazilian Amazon · LandSHIFT · alucR

\section{Introduction}

Land-use models describe the interplay between different driving factors within land systems (Schaldach et al. 2011; Verburg et al. 1999). They are often used to explore dynamics and envision plausible paths along which future land-use distribution could unfold, presented in the form of land-use scenarios. Most often, assessments aim to inform policy makers, identify hot spots of change, or raise 
awareness of undesired long-term developments within land systems. Environmental concerns about deforestation in the tropical regions around the world led to a large number of land-use change scenario analyses, especially within the Amazon biome (Dalla-Nora et al. 2014; Lapola et al. 2011).

Researchers have developed and applied land-use models for different scales, purposes, and regions. Methods vary between cellular automata or rule-based approaches, empirical or statistical models, agent-based models, macroeconomic models, land-use accounting models, and integrated approaches that combine different methodologies (Alcamo et al. 2006; Brown et al. 2014). The increasing understanding of the complexity of land-use change and linkages within the earth system (e.g., land-use changes that depend on teleconnections, indirect land-use changes, or displacement) calls for reconsidering the traditional understanding of a closed system at one spatial scale (Arima et al. 2011; Dalla-Nora et al. 2014; Gollnow and Lakes 2014; Lapola et al. 2010; Meyfroidt et al. 2013; Richards et al. 2014). However, such processes and feedbacks of indirect land-use changes from global to regional to local scales are rarely addressed in land-use modeling studies (Rosa et al. 2014).

Some of the most prominent scenario assessments refer to deforestation in the tropics, where global, regional, and local perspectives on climate regulation, biodiversity conservation, individual livelihood, and national interests, among others, meet. For the Brazilian Amazon, a number of scenarios have been published (Aguiar et al. 2016; Assis et al. 2011; Lapola et al. 2010, 2011; Laurance et al. 2001; Maeda et al. 2011; Moreira 2009; Oliveira et al. 2013; Rosa et al. 2013, 2014; Soares-Filho et al. 2001, 2004, 2006; Verburg et al. 2014; Wassenaar et al. 2007). Dalla-Nora et al. (2014) critically assessed key elements of the different scenarios and realized that most scenario models failed to capture the amount of deforestation over recent decades. Additional shortcomings relate to a lack of transparency in terms of quantifying, calibrating, and validating the models (Rosa et al. 2014). Recommendations for future scenario assessments include integrating global and regional models to improve the structure and consistency of Amazonian land-use/cover change assessments (Alcamo et al. 2006; Dalla-Nora et al. 2014). Cross-scale linkages of land-use change processes may be especially true for regions that are dominated by the production of agricultural goods for export markets. Soybean demand as animal fodder for European and Chinese markets has fueled the soybean industry in Brazil, where it has been linked to extensive conversions of natural vegetation (Arima et al. 2011; Brown-Lima et al. 2010; FAO 2015; Godar et al. 2016; Gollnow and Lakes 2014). Consequently, the increase in demand for animal fodder can be understood as an important driver of soybean expansion and deforestation in the Brazilian Amazon (DeFries et al. 2013; Macedo et al. 2012).

Multiscale modeling approaches to model deforestation and land-use change have been suggested by different authors. For example, Moreira et al. (2008) coupled a regional $\left(25 \times 25 \mathrm{~km}^{2}\right)$ with an agent-based $\left(1 \times 1 \mathrm{~km}^{2}\right)$ land-use model to assess future deforestation in São Félix do Xingu, embedded within the context of the Brazilian Amazon. The coupling covered the amounts of prospected deforestation and also included a bottom-up linkage in case the expected amount at the regional scale could not be allocated within the subregional model. This could occur, for example, if the network of protected areas were expanded or other restrictions on deforestation were implemented. Verburg et al. (1999) provided a spatially explicit modeling approach for Ecuador, coupling two spatial scales of analysis that both covered the entire country. The authors modeled the spatial linkages of the land-use changes between $9 \times 9$ and $35 \times 35 \mathrm{~km}^{2}$ grids, including top-down and bottom-up linkages. However, the spatial coarseness of both scales in the modeling experiment avoided common challenges of data comparability and accuracy at different spatial scales.

Data on the spatial configuration of land use and cover are a crucial input for most land-use models. It determines the initial land-use patterns within the study region. Most often, information on land use and cover derives from remote sensing data classification. Whereas high-resolution land-use data are often available only for selected regions of a defined extent, moderate- to coarse-resolution data are available on a global scale but may not be reliable for regional analysis (Herold et al. 2008; Kaptué Tchuenté et al. 2011). Combining different land-use data sets at different scales involves challenges related to spatial accuracy, precision, and the thematic comparability of the classifications. It remains challenging to develop and apply approaches that link different scales of land-use models, including different sources of spatial information on land use, to provide consistent scenarios across scales (Alcamo et al. 2006; Dalla-Nora et al. 2014).

The selected region for this study is situated within the federal states of Mato Grosso (MT) and Pará (PA) in Brazil along the BR-163 highway, which traverses the Amazon rainforest. MT became Brazil's largest soybean-producing state for export markets in recent decades (Brown-Lima et al. 2010; DeFries et al. 2013; Macedo et al. 2012). Soybean expansion came mostly at the expense of direct conversion of savanna in MT but also indirectly led to deforestation through pasture displacement and cattle ranching in MT and PA (Arima et al. 2011, 2015; Boucher et al. 2013; Gibbs et al. 2015; Gollnow and Lakes 2014; Richards et al. 2014). Particularly during the soybean boom 
in the early 2000s, land speculation, the strong appreciation in land value, and the expansion of cropland on pasture were linked to the displacement of cattle production, which led to the increased deforestation in the Amazon biome (Gollnow and Lakes 2014; Richards et al. 2014).

Within this setting, we explore multiscale land-use modeling for two scenarios. We coupled a regional scenario quantification and spatial allocation with a subregional allocation model and compared these with a subregional quantification. At the regional scale, we used the LandSHIFT modeling framework (Schaldach et al. 2011), and at the subregional scale, we used the alucR framework (Gollnow 2015). We used different land-use and cover maps with the two scales based on the availability of a reliable and detailed map (i.e., TerraClass) for the subregion (Almeida et al. 2016; INPE 2015). This map was not available for the spatial extent of the regional-scale model. Instead, we used the global land-cover product provided by MODIS (Friedl et al. 2010). Combining two data sets at the different scales required new approaches of model coupling between scales. Story lines of future regional development have been developed and quantified within the interdisciplinary project CarBioCial and discussed with selected stakeholders in Brazil (www.carbio cial.de).

We derived the following research questions:

1. What are the differences in the 2010 land use and cover maps between the subregional and the regional land-use classifications that will affect the results of the coupled land-use scenarios?

2. What are advantages of cross-scale modeling versus subregional model quantification of land-use change scenarios?

3. What are possible scenarios of land-use change along the BR-163 highway following coupled and subregional model quantification?

4. How does the amount of deforestation vary between the different scenarios?

\section{Methods}

\section{Study area}

The study area is situated within the Brazilian Amazon, along the BR-163 highway in the states of MT and PA (Fig. 1). These two states account for approximately $67 \%$ of the Brazilian Legal Amazon deforestation through 2015 and continue to present the highest forest loss rates among the Brazilian Legal Amazon states (INPE 2016). The region along the BR-163 has been one of the most dynamic forest frontiers in the two states (Fearnside 2007). At the regional level, we calculated land-use scenarios for both states. At the subregional level, we selected a buffer of $100-\mathrm{km}$ width along the BR-163 starting from Sinop in the south and reaching north to Morais de Almeida, south of Parque National do Jamaxim (Fig. 1). This corridor follows the dominant occupation history along the highway from south to north (Coy and Klingler 2010; Fearnside 2007; Müller et al. 2016). In MT, land use is dominated by largescale soybean, maize, and cotton production, mostly cultivated in double-cropping systems (Arvor et al. 2011; Lapola et al. 2014). Moving north toward the border of PA, a transition to large-scale cattle ranching occurs, with integrated crop and cattle management emerging (Gil et al. 2015). In the south of PA, cattle ranching is the dominant land use. Here, weak governance and uncertain land tenure rights prevail (Fearnside 2007; Gil et al. 2015; Richards 2012).

Following the increase in deforestation rates in the early 2000 s, a set of measures, policies, and institutional agreements were put into action to control and prevent deforestation within the region. Most important were the 2004 PPCDAm (Action Plan to Prevent and Control Deforestation in the Amazon); the Soy Moratorium, implemented in 2006; and the Beef Moratorium that was agreed on in 2009 (Boucher et al. 2013). The PPCDAm combines a series of strategies: expanding the protected areas network, increasing and improving monitoring, enforcing environmental laws, and supporting the Rural Environmental Registry (CAR) and sustainable production systems (MMA 2013). The Soy Moratorium and Beef Moratorium are pledges that were agreed to by the major soybean companies and beef traders, respectively, to ensure that their products would not be produced on newly deforested lands (Boucher et al. 2013). These actions, in combination with changes in global prices for agricultural goods, led to a $68.2 \%$ decrease in deforestation rates in 2015 compared with the past decade's (1996-2006) baseline (Assunção et al. 2012, 2013; Boucher et al. 2013; Gibbs et al. 2015; INPE 2016; Rudorff et al. 2011). However, in 2013, 2015, and 2016, deforestation increased, although at significantly lower rates compared with the beginning of the remote sensing monitoring program (INPE 2016).

\section{Land-use models and multiscale modeling}

We calculated spatially explicit scenarios of subregional land-use change for the BR-163 corridor following two approaches. The first was to combine two scales of analysis, which we referred to as coupled modeling. Here, we calculated land-use scenarios for MT and PA and used the results as input to quantify the amount of land-use change within the subregion along the highway. The second modeling approach quantified the scenario assumptions 


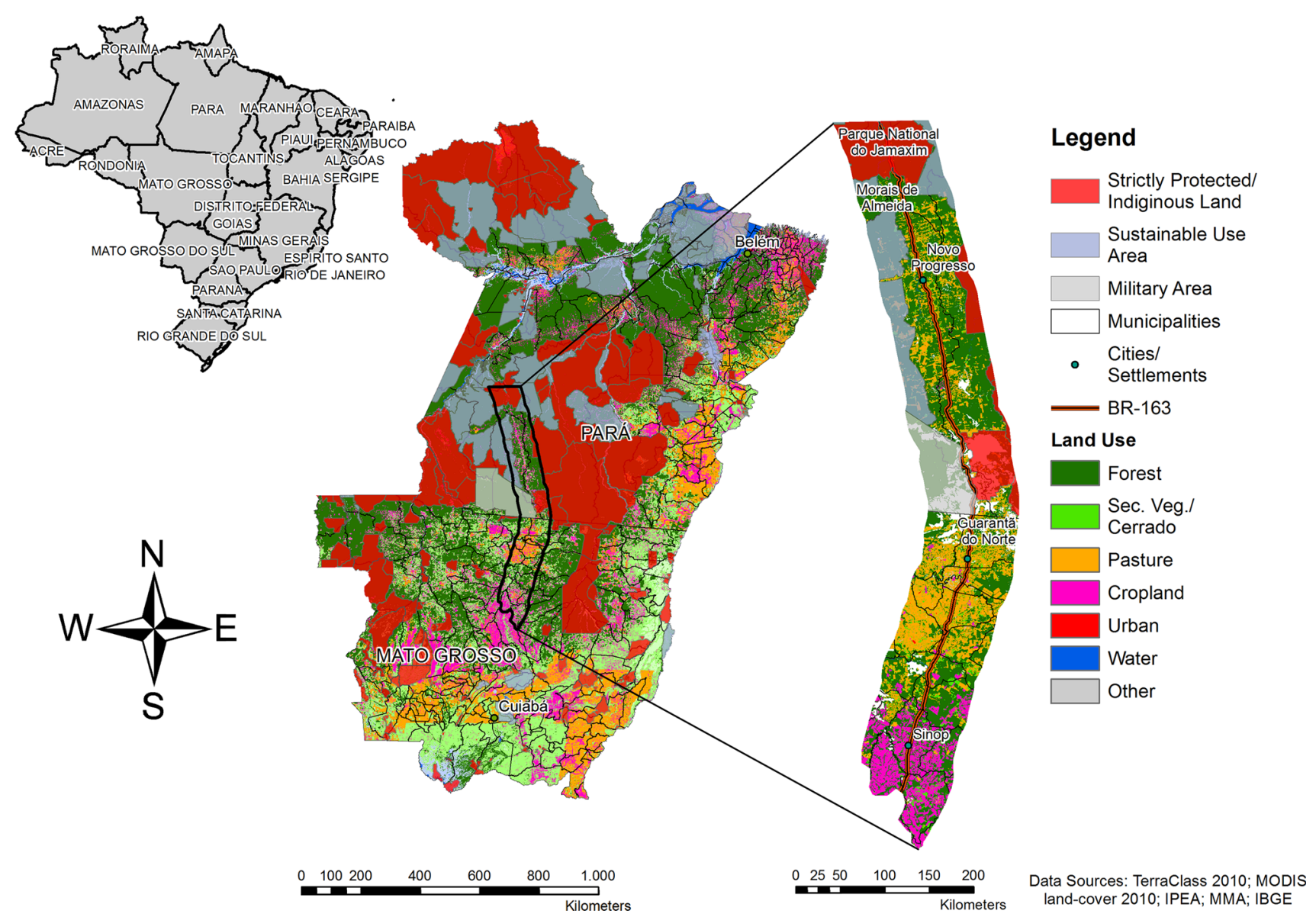

Fig. 1 Study region

derived from the story line based on spatially explicit data for the municipalities in the BR-163 subregion.

For the coupled modeling approach, we combined the scenario results from LandSHIFT with the alucR modeling framework. We describe each model in more detail below. When it was beneficial for the respective scale, we used different data sets for the different scales within the modeling frames (Table 1). Most important, we used a different land-use and cover maps for the initial land-cover distribution. At the subregional scale, we applied the TerraClass land-use classification (INPE 2015). For the regional MT and PA scenarios, we used the MODIS product (Friedl et al. 2010). The fine spatial resolution $\left(90 \times 90 \mathrm{~m}^{2}\right)$ of the subregional model allowed us to include the protection of riparian areas as determined by the Brazilian environmental law (Brazilian Forest Code, Federal Law 12.727 2012).

Both land-use modeling frameworks include a nonspatial macrolevel and a spatially explicit microlevel. The scenario quantification specifies the macrolevel. Here, quantitative future demands for agricultural production or land requirements and population change according to global and regional socioeconomic and agricultural developments are defined. At the microlevel, these land-use scenario demands are allocated spatially, and additional spatial restrictions (e.g., locations where no land-use conversion is allowed) are defined.

\section{LandSHIFT}

The LandSHIFT modeling framework was designed for regional- to global-scale land-use scenario analysis and has been tested for different case studies in Brazil (Alcamo et al. 2011; Lapola et al. 2010, 2011; Schaldach et al. 2011). It is organized into land allocation submodules that correspond to the different land-use subsystems: settlement, cropland, and pasture based on Turner et al. (2007). A multicriteria analysis determines the suitability of a certain location for cropland, pastures, and settlements, including those factors provided in Table 1 . The allocation follows a defined hierarchy: First, settlement areas are distributed; second, cropland; and third, pastureland, each at its most suitable location. Amounts of cropland change depend on the potential crop yields provided by the LPJmL model (Bondeau et al. 2007) in combination with the scenario assumptions. Changes in pasture area depend on the net primary productivity of the locations, also provided from the LPJmL model, and the scenario assumption relating to the 
Table 1 Data sets for model specifications

\begin{tabular}{|c|c|c|c|}
\hline Data category & Description & Model & Source \\
\hline \multirow[t]{2}{*}{ Land-use/cover } & Land-use/cover (TerraClass 2010, 2014) & alucR & INPE (2015) \\
\hline & Land-use/cover (MODIS 2010) & LandSHIFT & MCD12Q1, GLCF (2014) \\
\hline \multirow[t]{11}{*}{ Suitability factors } & Slope & LandSHIFT/alucR & $\begin{array}{l}\text { SRTM (United States Geological Survey } \\
\text { (USGS) 2000) }\end{array}$ \\
\hline & River density & LandSHIFT & $\begin{array}{l}\text { Density (LandSHIFT): Lehner and Grill } \\
\text { (2013) }\end{array}$ \\
\hline & Distance to rivers & alucR & $\begin{array}{l}\text { Distance (alucR): Agência Nacional de } \\
\text { Águas-ANA (2010) }\end{array}$ \\
\hline & Distance to roads (all, paved, unpaved) & LandSHIFT/alucR & IBGE (2010b) \\
\hline & $\begin{array}{l}\text { Precipitation 2000-2008 (mean, min, } \\
\text { max) }\end{array}$ & alucR & NASA (2015) \\
\hline & Distance to cities & alucR & TerraClass 2010 Urban (INPE 2015) \\
\hline & $\begin{array}{l}\text { Aptitude for mechanized crop } \\
\text { production (1: very aptitude; } 2 \text { : } \\
\text { aptitude; 3:not aptitude) }\end{array}$ & alucR & Soares-Filho et al. (2014) \\
\hline & Elevation & LandSHIFT & $\begin{array}{l}\text { SRTM30 (United States Geological } \\
\text { Survey (USGS) 2000) }\end{array}$ \\
\hline & Distance to major markets & LandSHIFT & ESRI (2000) \\
\hline & Crop yields, grassland NPP & LandSHIFT & LPJmL model (Bondeau et al. 2007) \\
\hline & Global livestock density & LandSHIFT & Wint and Robinson (2007) \\
\hline \multirow[t]{4}{*}{ Spatial rules } & Protected areas: strictly protected areas & LandSHIFT/alucR & SP, IL, SU: MMA (2015) \\
\hline & $\begin{array}{l}\text { (SP); indigenous lands (IL); } \\
\text { sustainable use areas (SU); military } \\
\text { areas (MA) }\end{array}$ & & $\begin{array}{l}\text { MA: Zoneamento Ecológico-Econômico } \\
\text { da Rodovia BR-163 (ZEE) (2008) }\end{array}$ \\
\hline & $\begin{array}{l}\text { Riparian protected areas (RPA): } \\
\text { estimated based on river dataset (max. } \\
90 \mathrm{~m}, \text { min } 60 \mathrm{~m} \text { buffer) }\end{array}$ & alucR & Agência Nacional de Águas-ANA (2010) \\
\hline & $\begin{array}{l}\text { Areas deforested before } 2006 \text { (derived } \\
\text { from PRODES) }\end{array}$ & alucR & INPE (2016) \\
\hline \multirow{3}{*}{$\begin{array}{l}\text { Main datasets for } \\
\text { the scenario } \\
\text { quantification } \\
\text { at macrolevel }\end{array}$} & $\begin{array}{l}\text { Crop production(in tons/year and ha/ } \\
\text { year) for 1974-2010) (see Table S.4) }\end{array}$ & LandSHIFT/alucR & IBGE (2016) \\
\hline & $\begin{array}{l}\text { Livestock units 1974-2007 (FAO } \\
\text { (2002)) (see Table S.4) }\end{array}$ & LandSHIFT/alucR & IBGE (2013) \\
\hline & Population estimates & LandSHIFT/alucR & IBGE (2010a) \\
\hline
\end{tabular}

development of the livestock sector. The scenarios may also include a certain rate of agricultural intensification (Schaldach et al. 2011). The initial land-use map combines a reference map and a quasi-optimal distribution of the land-use types derived from official statistics on agricultural production and population. Here, we combined the MODIS land-cover product resampled to $900 \times 900 \mathrm{~m}^{2}$ with official census data acquired from the Brazilian Institute of Geography and Statistics (IBGE 2015) to generate a representation of land uses in MT and PA.

\section{alucR}

The alucR model framework follows a statistical evaluation of land-use suitabilities. Similar to LandSHIFT, the land-use types are urban areas, cropland, and pastureland. We used best subset logistic regression analysis to estimate the locational suitability for each land-use class (McLeod and $\mathrm{Xu}$ 2015).We selected the spatial factors for estimating suitability based on earlier studies and have summarized them in Table 1 (Aguiar et al. 2007; Espindola et al. 2012). Our model selection was guided by the Akaike information criteria (AIC). The AIC evaluates the trade-off between model complexity and model fit (McLeod and $\mathrm{Xu}$ 2015). Amounts of land use defined at the macrolevel are allocated according to the relative suitability for each land-use class (Gollnow 2015). This allocation procedure is generally described as simulating the competition between land uses (Verburg et al. 2006). 
We calibrated the competition between land-use classes according to the transition and persistence of land uses, defined within the trajectory and elasticity matrix (Tables S.1 and S.2). The elasticity settings build the core part of the calibration process. They adjust the suitability values for a certain land use based on the current land-use categories. For example, a pixel classified as urban is very likely to stay urban in the next year rather than being relocated. This is why the suitability for urban use at this location should be increased to guarantee class persistence. We calibrated the model according to the elasticities using TerraClass 2014, the most recent year of comparable landuse information. We iteratively adjusted the elasticities based on the overall accuracy of the land-use change maps considering all observations. We calculated the accuracy by comparing the "true" changes between the TerraClass 2010 and 2014 classifications with the modeled changes for 2014, allocating the observed amounts of change derived from the TerraClass maps.

Spatial restrictions play an important role in both landuse modeling approaches. Depending on the scenarios, spatial restriction of land-use change refers to strictly protected areas, indigenous land, sustainable use areas, military areas, and protected riparian areas.

\section{Scenario building}

We selected two scenarios that were developed as part of CarBioCial. They describe qualitative (story lines) and quantitative developments with a focus on the BR-163 highway. The story lines encompass possible ecological, societal, economic, and political developments in the study region until 2030 and were translated into their potential meaning for population change, agricultural development, and land-use policy, following a similar structure to the story and simulation approach described by Alcamo (2008). We extracted statements from the story lines that referred to each of the three groups and interpreted them in terms of their potential meaning for the land-use modeling process (Table 2). We then translated these qualitative interpretations into either numerical values of agricultural production and population change or spatially explicit land-use change constraints, referring to protected areas or the Soy Moratorium (no cropland expansion in areas deforested after 2006) and Beef Moratorium (no pasture expansion in areas deforested after 2010). We extrapolated past trends derived from regional statistics and adjusted them following the scenario assumptions.

In brief, the Trend story line describes the continuation of current land-use practices characterized by increasing demands for agricultural goods, the paving of the BR-163 highway, and ongoing intensification of agrarian production. Increasing trends in crop and cattle production and population changes are the dominant drivers for calculating future land requirements. In this story line, protected areas play an important role for preserving the primary rainforest. However, inadequate monitoring and law enforcement was expected to lead to a de facto reduction of protected area size. We derived the numerical values for agricultural production and population changes for the scenario period of 2010 to 2030 by least-squares linear extrapolation of historical trends from 1973 to 2000 (Table S.3).

The second scenario story line was developed under the premises of Sustainable Development. The main foci with respect to the quantification process were a global and national change to a vegetarian-oriented diet, a regional reduction in population growth, and an increase in crop productivity. Expected sociopolitical changes included a social model of participation, citizenship, and law enforcement, food sovereignty, local sustainable development initiatives, a growing demand for certified agrarian goods, and clarification of land rights.

\section{The model coupling approach}

For our coupled modeling approach, we translated from story line to numerical values based on the regional statistics for MT and PA between 1973 and 2000. The derived quantifications summarized in Table 2 served as input for LandSHIFT, which generated spatially explicit land-use change scenarios for MT and PA at five-year intervals. We extracted the amount of land-use change for the BR-163 corridor subregion from the LandSHIFT regional scenarios and input them into alucR (Fig. 2). We applied simple linear interpolation for each year between the five-year model steps generated by LandSHIFT to disaggregate the quantities to the annual land-use changes required for alucR.

\section{Subregional approach}

The subregional land-use modeling approach followed the more traditional quantification process based on the historic development of the subregion (Fig. 2). We used past developments derived from the intersecting municipalities (1973-2000) along the BR-163 corridor to translate the story lines into numerical values for agricultural production and population change (Table S.4). We spatially allocated the derived quantities of land-use change with the same alucR model as that for the subregion in our coupled modeling.

\section{Data}

Detailed information on land-use and cover as input for the land-use models is crucial for computing scenarios of future land-use distribution. At the subregional scale, the Brazilian Institute for Space Research (INPE) provided a 
Table 2 Main aspects of the story line quantification (see Table S.6 for story lines)

\begin{tabular}{|c|c|c|}
\hline Storyline assumption (Portuguese) & Scenario interpretation & Quantification \\
\hline \multicolumn{3}{|l|}{ Trend scenario } \\
\hline \multicolumn{3}{|l|}{ Population change } \\
\hline $\begin{array}{l}\text { “...]a expansão de monoculturas e a } \\
\text { concentração da terra no setor agrário, tendo } \\
\text { como consequência a deslocação forçada } \\
\text { contínua de trabalhadores rurais, agricultores } \\
\text { familiares e pecuaristas de menor eficiência } \\
\text { econômica. Uma parte dos deslocados } \\
\text { encontrará trabalho nas novas aglomerações } \\
\text { urbanas ao longo da BR-163, enquanto } \\
\text { outros seguirão ao Norte da região, }\end{array}$ & $\begin{array}{l}\text { The story line describes the continuation of } \\
\text { current trend of population growth and } \\
\text { migration developments }\end{array}$ & $\begin{array}{l}\text { Least-squares extrapolation of urban } \\
\text { population changes observed between } 1974 \\
\text { and } 2010 \\
\text { alucR: Estimated change rates were converted } \\
\text { to area changes in relation to observed urban } \\
\text { areas in TerraClass in } 2010 \\
\text { LandSHIFT: Urban area changed according to } \\
\text { the estimated population changes }\end{array}$ \\
\hline
\end{tabular}
adiantando a conversão de floresta em pasto e lavoura na Amazônia. Em geral, se observa um crescimento de centros urbanos regionais. Por consequência, se ampliará o setor terciário. Essas cidades jovens apresentam configurações rural-urbanas específicas: muitas vezes os produtores agrários possuem residência na área urbana, dissolvendo assim a divisão clássica entre o meio urbano e o meio rural"

\section{Agricultural development}

“A estrutura da produção agrícola varia ao longo da rodovia de $1.780 \mathrm{~km}$ : no Mato Grosso, a dependência de multinacionais agrárias, a qual restringe as margens para decisões de inovação por causas econômicas, cresce proporcionalmente com a capitalização e as monoculturas (soja, milho, algodão)"

Monocultures of soybeans, corn and cotton continue to dominate the land use. Multinational companies mostly interested in economic growth dominate the production process

Cattle farming continues as an extensive, land demanding production system. Livestock production and need for pasture land continues to rise da produção.[...] Como não há zoonoses, se incrementa a produção de carne na região inteira, sobretudo de carne bovina"

\section{Land-use policy}

"Existem numerosas áreas de proteção no Pará e no Mato Grosso, mas com uma administração deficiente, e raramente com monitoramento participativo. Ainda assim, possuem um papel importante na preservação de recursos naturais e da terra.[...] Os zoneamentos no nível macro, a falta de implementação da lei e a falta de recursos nos órgãos de fiscalização, juntos à pressão crescente sobre a terra, resultam no fato de que as reivindicações de justiça social contribuam para a diminuição das áreas de proteção"
Land-use conversations within protected areas are limited, but due to poor monitoring some illegal conversions occur. These result in a de facto reduction of protected areas size
Least-squares extrapolation of past changes of crop production corrected for yield increases between 1974 and 2010 including the crop types listed in Table S.4

alucR: Estimated change rates were converted to area changes according to cropland area in TerraClass in 2010

LandSHIFT: Tons of production was allocated according to land productivity derived from the LPJmL model

Least-squares extrapolation of past changes of livestock units (FAO 2002) between 1974 and 2007

alucR: Estimated percent changes of livestock units were converted to area changes and applied to pasture area in TerraClass 2010

LandSHIFT: Livestock units were allocated according to grassland productivity derived from LPJmL model

alucR: Land-use conversions in sustainable use areas were allowed every secondnd year and in strictly protected and indigenous areas conversion every fourth year. No conversion in military areas

LandSHIFT: No land-use conversions in protected, indigenous and military areas are allowed 
Table 2 continued

\begin{tabular}{|c|c|c|}
\hline Storyline assumption (Portuguese) & Scenario interpretation & Quantification \\
\hline \multicolumn{3}{|l|}{ Sustainable development scenario } \\
\hline \multicolumn{3}{|l|}{ Population change } \\
\hline $\begin{array}{l}\text { “A migração para a região pode crescer } \\
\text { devido ao clima social favorável. Como não } \\
\text { haverá migração por causa de deslocamento } \\
\text { forçado, resultado de fatores socio- } \\
\text { econômicos, a necessidade da migração } \\
\text { inter-regional deixa de existir. No lugar } \\
\text { deste tipo de migração, observa-se a } \\
\text { migração inter-regional de profissionais e } \\
\text { uma migração intra-regional equilibrada, } \\
\text { ocasionado pela atração crescente das } \\
\text { cidades médias. complementa-se o cenário } \\
\text { pelo crescimento endógeno do espaço } \\
\text { urbano e assim a estabilização da classe } \\
\text { média urbana, que continua defendendo a } \\
\text { sustentabilidade e justiça rural e urbana” }\end{array}$ & $\begin{array}{l}\text { Inter-regional and intra-regional migration } \\
\text { decreases, leading to a decrease in the } \\
\text { projected population growth from the trend } \\
\text { scenario }\end{array}$ & $\begin{array}{l}\text { Trend projections of population increase } \\
\text { adjusted by a decrease of } 7.5 \% \text { every } 5 \text { years }\end{array}$ \\
\hline \multicolumn{3}{|l|}{ Agricultural development } \\
\hline $\begin{array}{l}\text { "O papel de uma demanda que exige } \\
\text { sustentabilidade ficou mais importante, } \\
\text { assim, as moratórias de soja e de carne } \\
\text { bovina, com respeito às exigências para a } \\
\text { produção sustentável, são bem consolidadas, } \\
\text { e os clientes as respeitam, seguindo a } \\
\text { tendência global para um consumo de } \\
\text { produtos sustentáveis. Na política local, } \\
\text { ademanda externa e os efeitos dela são bem } \\
\text { administrados. As distorções de preços no } \\
\text { mercado mundial por subvenções (algodão, } \\
\text { milho, leite...) se reduziram gradualmente; } \\
\text { os produtos não certificados quase não } \\
\text { encontram demanda, e as quotas de mercado } \\
\text { para produtos ecologicamente produzidos } \\
\text { aumentam, por exemplo para soja, carne e } \\
\text { óleo de dendê. Incentivados pela estrutura da } \\
\text { demanda, que visa a sustentabilidade, os } \\
\text { mercados se adaptaram amplamente às } \\
\text { formas agroecológicas de produção" }\end{array}$ & $\begin{array}{l}\text { The demand on certified ecologically } \\
\text { produced plant-based products increases. } \\
\text { This is supported by a global trend toward } \\
\text { certification and less meat-oriented diets }\end{array}$ & $\begin{array}{l}\text { Trend projections of plant-based products } \\
\text { adjusted by an increase for beans, fruits, } \\
\text { vegetables, and soybeans (corrected for } \\
\text { export losses due to decreasing demands for } \\
\text { animal fodder) }\end{array}$ \\
\hline $\begin{array}{l}\text { "De acordo com as apresentações acima, a } \\
\text { população de gado é menor que nos outros } \\
\text { cenários, por restrições impostas, assim } \\
\text { como queda na demanda devido às } \\
\text { mudanças nos hábitos alimentares" }\end{array}$ & $\begin{array}{l}\text { Livestock numbers decrease significantly, } \\
\text { mostly due to changes in diets and } \\
\text { certification needs }\end{array}$ & $\begin{array}{l}\text { Livestock reduction and accordingly pasture } \\
\text { reduction by } 70 \% \text { compared to the projected } \\
\text { trend scenario until } 2030\end{array}$ \\
\hline \multicolumn{3}{|l|}{ Land-use policy } \\
\hline $\begin{array}{l}\text { "No contexto do zoneamento todas as } \\
\text { categorias de proteção foram revisadas, } \\
\text { resultando em um consenso em relação à } \\
\text { preservação de áreas de proteção existentes e } \\
\text { à não exploração de áreas florestais. Isso } \\
\text { resulta numa legislação de não exploração, } \\
\text { incluindo o fomento às alternativas } \\
\text { econômicas e pagamentos compensatórios" }\end{array}$ & $\begin{array}{l}\text { The sustainability scenario focuses on the } \\
\text { certification of production implemented with } \\
\text { the Soy and Beef Moratorium. Similarly, } \\
\text { protected areas are well monitored and } \\
\text { hence will not exhibit changes in land use }\end{array}$ & $\begin{array}{l}\text { No conversion of land within protected areas } \\
\text { (strictly protected areas, indigenous areas, } \\
\text { and sustainable use areas). No conversion of } \\
\text { areas deforested after } 2006 \text { to cropland or } \\
\text { deforested after } 2009 \text { to pasture }\end{array}$ \\
\hline
\end{tabular}

detailed map of postdeforestation land-use, TerraClass, available for the years 2004, 2008, 2010, 2012, and 2014, with a minimum mapping unit of 6.25 ha $\left(250 \times 250 \mathrm{~m}^{2}\right)$. These maps are based on visual interpretation of Landsat satellite data in combination with MODIS phenology data and the PRODES deforestation mask (Almeida et al. 2009, 2016; INPE 2015, 2016).

Such detailed information was not available at the regional scale throughout all of MT and PA. Instead, we employed the 2010 MODIS product $\left(500 \times 500 \mathrm{~m}^{2}\right)($ Friedl et al. 2010$)$, 


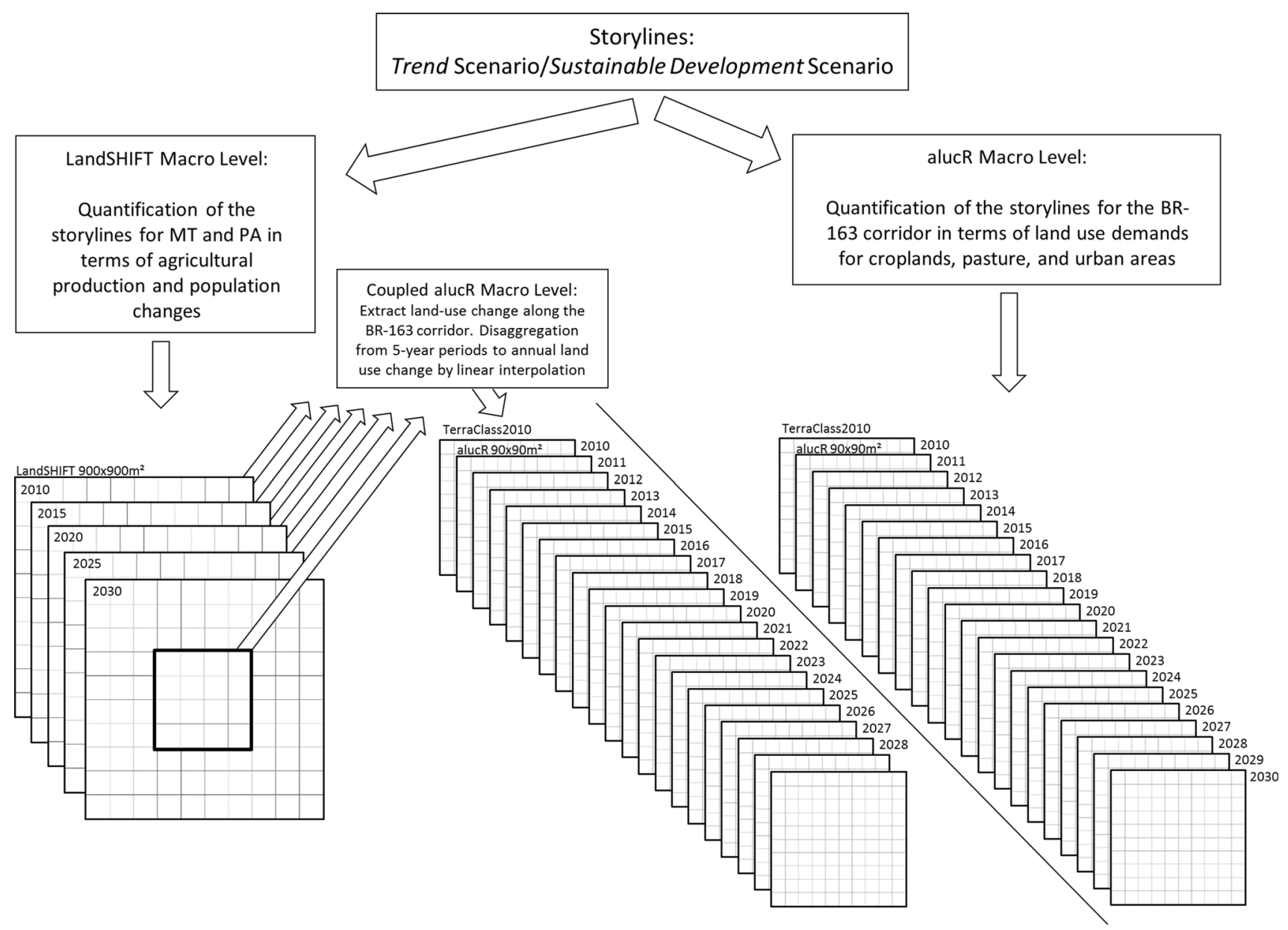

Fig. 2 Schematic figure of the coupled modeling (left) and the subregional quantification (right)

aggregated to $900 \times 900 \mathrm{~m}^{2}$, to initiate the regional-scale land-use modeling. In LandSHIFT, we spatially allocated land use as derived from agricultural statistics on crop types, livestock units, and population counts at the locations of the relevant land-cover classes, following a quasi-optimal allocation algorithm (Schaldach et al. 2011). We hereafter refer to the resulting land-use map as LandSHIFT 2010.

We harmonized the land-use classes between the two maps to match similar categories between TerraClass 2010 and LandSHIFT 2010. The categories were croplands, pastures, urban areas, forests, secondary vegetation, water, and other land-use and cover types (Table S.5). We based the suitability analyses for cropland, pastureland, and urban areas on the data summarized in Table 1.

We included different categories of protected areas in the scenarios (Table 2). If protection was enforced, the model prevented any expansion of land use within those areas. Additionally, the Sustainable Development scenario stressed the demand for certified agrarian goods. As such, we prohibited cropland expansion in areas deforested after 2006 (Soy Moratorium) and pasture expansion in areas deforested after 2010 (Beef Moratorium).

\section{Results}

The results are organized as follows. First, we provide a quantitative comparison between the two initial land-use data sets for the BR-163 corridor. Second, we describe the differences in the dynamics between the two states and the BR-163 subregion. Third, we compare and present the coupled and noncoupled scenario quantifications for the corridor. Finally, we describe the spatially explicit scenario results along the corridor and quantify the amount of deforestation until 2030.

\section{Comparison of LandSHIFT 2010 and TerraClass 2010 harmonized land-use classifications for the BR- 163 corridor}

The amounts and spatial distributions of the initial land uses were critical for the process of coupling models across scales and for assessing future land-use change scenarios. Here, we present the differences between the two land-use maps, LandSHIFT 2010 and TerraClass 2010, for the BR-163 corridor. We found differences in both area and spatial 


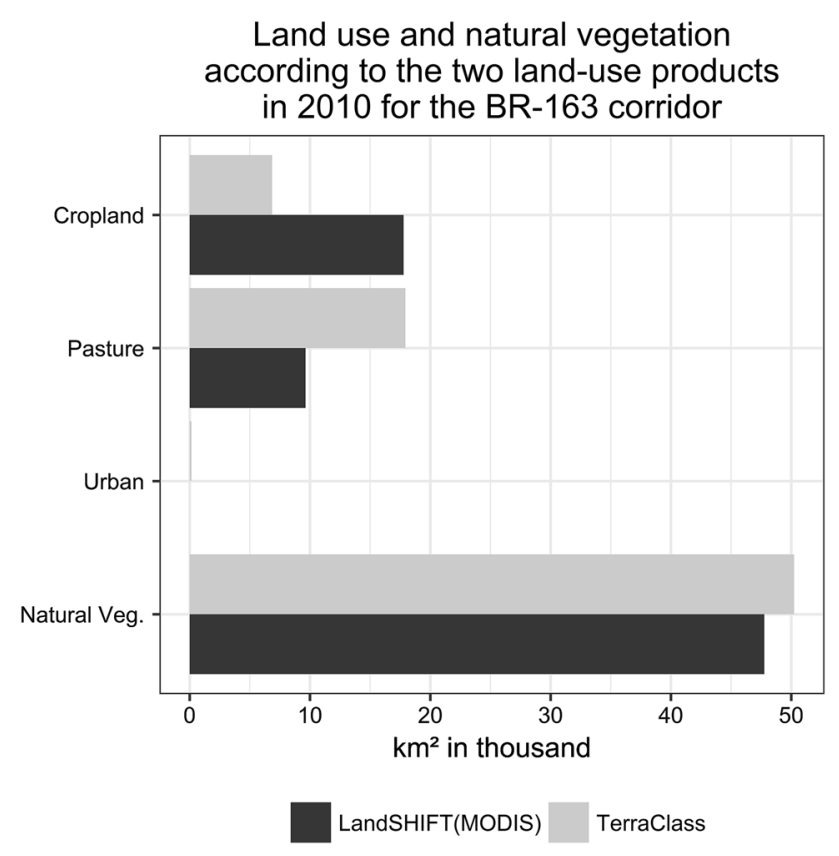

Fig. 3 Land use and natural vegetation (forest and secondary vegetation) along the BR-163 in 2010 according to the initial landuse and cover maps (LandSHIFT 2010 and TerraClass 2010)

distribution of land use and cover (Figs. 3, 6). In total area, TerraClass 2010 reported approximately twice the amount of pasture within the corridor than LandSHIFT 2010 (TerraClass 2010: 17,862 km² ; LandSHIFT 2010: $9638 \mathrm{~km}^{2}$ ). Areas defined as cropland within TerraClass 2010 made up less than half the area defined in LandSHIFT 2010 (TerraClass 2010: $6863 \mathrm{~km}^{2}$; LandSHIFT 2010: 17,862 $\mathrm{km}^{2}$ ). Urban areas were scarce in LandSHIFT (TerraClass 2010: $15 \mathrm{~km}^{2}$; LandSHIFT 2010: $3 \mathrm{~km}^{2}$ ). Natural vegetation cover, which combined forest and secondary vegetation (Table S.1), covered a larger area in TerraClass (TerraClass 2010: $50,246 \mathrm{~km}^{2}$; LandSHIFT 2010: $47,758 \mathrm{~km}^{2}$ ). A spatial comparison between the two maps indicated large differences in the northern part of the corridor. TerraClass 2010 identified mainly pasture areas in PA, whereas LandSHIFT 2010 classified large areas in southern PA as cropland (Fig. 6). Within the central part of the corridor (north of MT), pasture use was dominant in TerraClass 2010, but a mosaic of croplands and pastures was present in LandSHIFT 2010. In the south of the study area (north-central MT), we found similar land-use patterns, dominated by croplands within both classifications.

\section{Comparison of the land-use change dynamics at the regional scale versus the subregional BR-163 corridor, derived from the coupled scenario quantification}

The Trend scenario: Pasture expansion was the dominant land-conversion process (Fig. 4a). Especially in the second half of the scenario period, the BR-163 corridor was a hot spot of pasture expansion. In contrast to the slight decrease in cropland along the BR-163 corridor, the MT and PA areas experienced a slight overall expansion of cropland until 2030.

The Sustainable Development scenario: The coupled Sustainable Development scenario estimated a strong increase in land allocated for crop production and a decrease in pasture area (Fig. 4b). This dynamic was less strong along the BR-163 corridor compared with the state (MT and PA) level. On the one hand, this suggests that the BR-163 is less prone to large-scale crop expansion than are other regions in MT and PA, but on the other hand, a greater decrease in pastureland for all of MT and PA suggests the BR-163 region as more suitable for pasture.

Urban area demand increased slightly under the Trend and decreased slightly under the Sustainable Development scenarios in MT and PA. However, urban areas along the BR-163 corridor were left unchanged.

\section{Comparison of the subregional dynamics along the BR-163 corridor between the coupled and noncoupled model quantifications}

The Trend scenario: The main difference between the two quantification approaches manifested in different cropland change dynamics. The subregional quantification estimated a stronger expansion of cropland than did the coupled quantification (Fig. 4c). We found an increase in cropland of more than 5\% along the BR-163 corridor until 2030 following the subregional trend extrapolation compared with a reduction of $0.3 \%$ estimated from the coupled approach. Land allocated for pasture increased in both approaches, though the increase was stronger in the subregional quantified scenario. In 2030, the estimated pasture increase differed by only $2 \%$. Urban areas along the BR-163 were estimated to expand in the subregionally quantified scenarios (by $0.2 \%$ ) but not in the coupled approach.

The Sustainable Development scenario: The subregional quantification of the Sustainable Development scenario resulted in an extensive reduction of pastureland (Fig. 4d). This was caused by the assumptions of a $70 \%$ reduction of livestock by 2030 compared with the Trend scenario. Cropland expansion along the BR-163 was greater with the coupled quantification approach. Cropland expanded by roughly 6\% compared with a $1 \%$ increase for the subregional quantification. Urban area increased by $0.1 \%$ for the subregional quantification. 

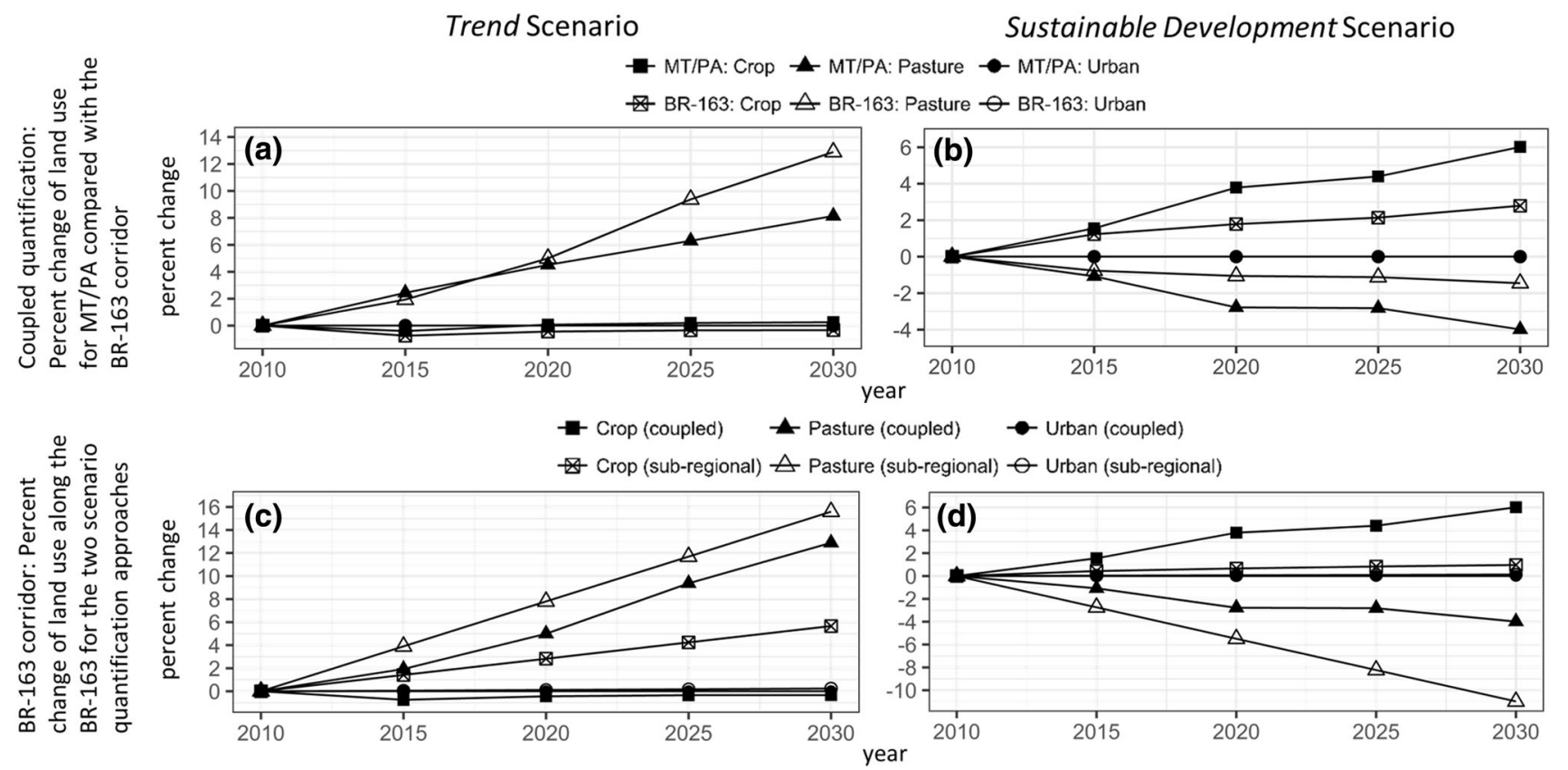

Fig. 4 Comparison of the land-use changes in a, b MT and PA versus the subregion derived from the coupled quantification and $\mathbf{c}, \mathbf{d}$ the landuse changes derived from the coupled and subregional quantifications of the BR-163 corridor

\section{Spatial explicit land-use change and deforestation estimates}

We iteratively calibrated the subregional land-use model based on two available land-use classifications, the 2010 and 2014 TerraClass. During the calibration, we adjusted the model elasticities based on the cross-tabulated error matrix of all observations. The overall accuracy of the modeled land-use change map, compared with the "true" land-use change map, reached $91 \%$.

Estimates of deforestation along the BR-163 between 2010 and 2030 differed substantially between the scenarios and between the quantification approaches. The subregional quantification of the Trend scenario resulted in nearly double the amount of deforestation of that in the coupled approach (Fig. 5a: $7250 \mathrm{~km}^{2}$, coupled; $13,207 \mathrm{~km}^{2}$, subregional). The Sustainable Development scenario quantified at the subregional level resulted in the lowest deforestation rates (Fig. $5 \mathrm{~b}: 1.5 \mathrm{~km}^{2}$ ). The coupled Sustainable Development scenarios had lower deforestation rates than those in the Trend scenario but higher rates than in the subregional quantification (Fig. $5 \mathrm{~b}: 213 \mathrm{~km}^{2}$, coupled).

The spatial allocation of land-use change followed the historic expansion patterns (Fig. 6). Cropland expanded in the south of the study region, pasture in the center and north, and urban areas around the current urban centers. The Trend scenario indicated tremendous pressure on the conversion of land by converting the last remnants of natural vegetation in the south and center of the study region to either crop or pasture. The pasture expansion hot spots were simulated to stretch along the highway around Novo Progresso and in the north of MT. Secondary vegetation is most likely to occur in the area between Sinop and Guarantã do Norte and in distant areas away from the BR163 highway in PA.

\section{Discussion}

In this study, we analyzed the differences in two land-use change scenarios between using coupled and noncoupled scenario quantification approaches. The coupled approach combined two land-use models that ran at different scales. The LandSHIFT modeled land use for the whole of the states of MT and PA and was coupled to alucR, which simulated land-use dynamics for a subset of these states along the BR-163 highway. We compared the coupled model results with those from using noncoupled subregional quantification for the BR-163 corridor.

We partly expanded earlier approaches of coupled landuse change assessments to take advantage of different landuse maps available at different scales. Whereas earlier approaches assessed land-use changes across scales to improve the local understanding of processes, they used the same land-use maps at different aggregation levels. However, from regional to global scales, explicit spatial landuse information often relies on global assessments of land- 


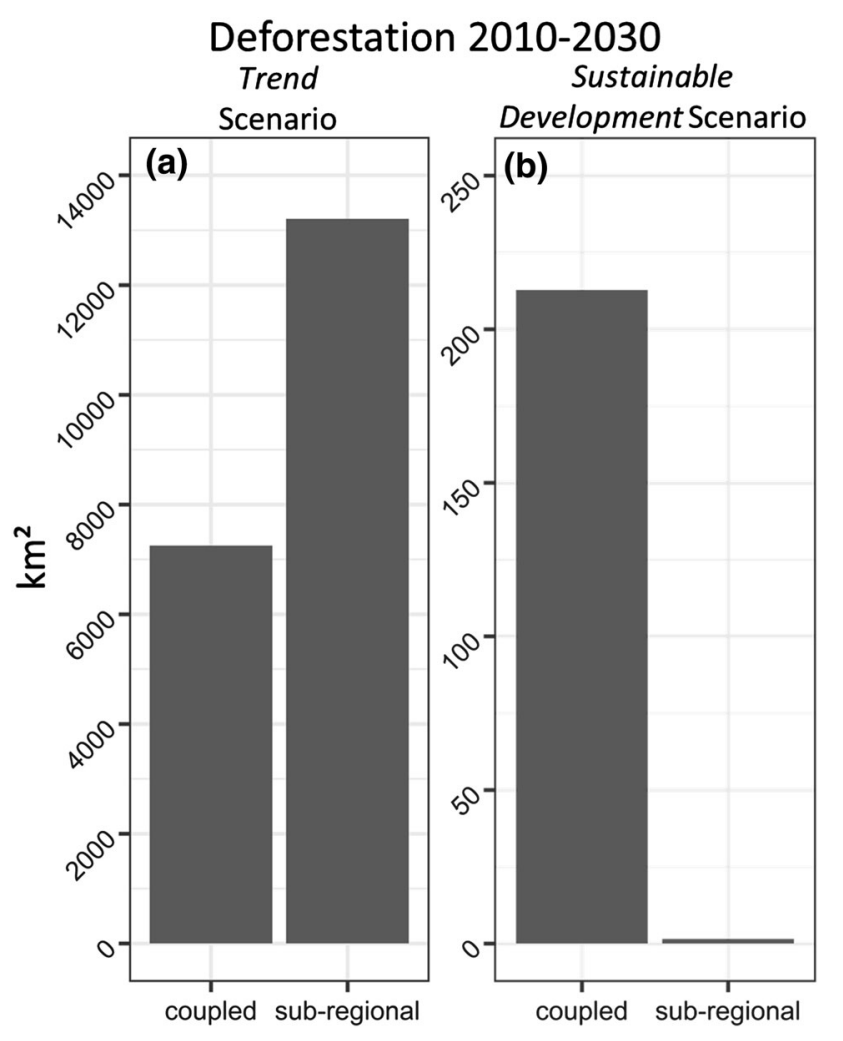

Fig. 5 Deforestation in kilometers squared according to the different scenarios and quantification approaches within the BR-163 corridor

use and cover (e.g., MODIS, GLC-2000, and GlobCover), which have been identified to have inappropriate accuracies for regional assessments (Fritz et al. 2011). Because inaccuracies in the land-use and cover distribution can be expected to persist throughout the scenario development, we argue that the reliability of scenario results crucially depends on the regional accuracy of the initial land-use data. Additionally, the detailed and official character of TerraClass 2010 gives the classifications high credibility for subregional assessments (INPE 2015). Still, one could argue for the use of TerraClass 2010 for both the regional (LandSHIFT) and subregional (alucR) models. The limited spatial extent of TerraClass 2010, defined by the boundaries of the Amazon biome, did not cover the full extent of MT, which made it impossible to use for LandSHIFT under the current modeling setup.

Differences in land use and cover that affected the coupled scenario assessment between scales related to the amounts and spatial locations. The comparison indicated large differences between land use and cover for the year 2010 , mostly related to confusion between cropland and pasture and to disagreements in the amounts of urban land. In the north of the study area, land in TerraClass 2010 was dominated by pasture, whereas LandSHIFT 2010 allocated a considerable amount to cropland. This is likely
Fig. 6 Spatial representation of the Trend and Sustainable Development land-use change scenarios in 10-year intervals; regional scenarios covering MT and PA (top) and the two quantification approaches at the subregional scale along the BR-163 corridor (bottom)

attributable to the spectral similarity between pasture and cropland, which led to class confusions based on the MODIS land-cover classifications. Urban area differences may relate to the large difference in spatial resolution, and coupling the scenario analysis can increase the spatial representation of land uses at the subregional scale compared with regional scenario results.

We adapted the coupling procedure from earlier studies (Moreira et al. 2008; Verburg et al. 1999). Rather than passing the total amount of land use from one model to the other, we coupled the amount of change. This adaptation was necessary because of the differences between the two land-use maps. We could argue that coupling the amount of change in land use from the regional to the subregional scale preserves the advantages of scenario consistency between scales (i.e., captures land-use dynamics between scales), while at the same time it sustains the accuracy of the subregional land-use map. In summary, the advantage of cross-scale modeling is that it improves the legitimacy (improved spatial representation of land uses at the subregional level) and consistency (land-use dynamics are consistent from the regional to the subregional scale) of the scenario results for large-scale analysis, which provides more accurate details at the subregional scale.

The coupled approach is capable of capturing processes of land-use displacement (e.g., conversions of pasture to cropland leading to pasture expansion elsewhere) that can affect deforestation or similar land-use changes within a subregion (Arima et al. 2011; Gollnow and Lakes 2014; Lapola et al. 2010). Accordingly, displacement passed from the regional to the subregional scale in theory leads to greater land-use changes (pasture expansion) in the coupled scenario quantification. Partly contradictive to our expectation, the analysis did not indicate stronger land-use change dynamics derived from the coupled quantification approach. Instead, the subregional quantification in the Trend scenario led to the highest land-use change rate. This can be explained by the quantification process, specifically the extrapolation of past trends. Displacement effects were already captured within the subregional quantification because the municipality statistics used for extrapolation included those dynamics within the time series (Arima et al. 2011; Gollnow and Lakes 2014; Lapola et al. 2010). Considering this, we recommend taking advantage of multiscale modeling when cross-scale land-use processes (e.g., indirect land-use changes) are expected to change from previous developments and are not yet captured in a subregional trend. 


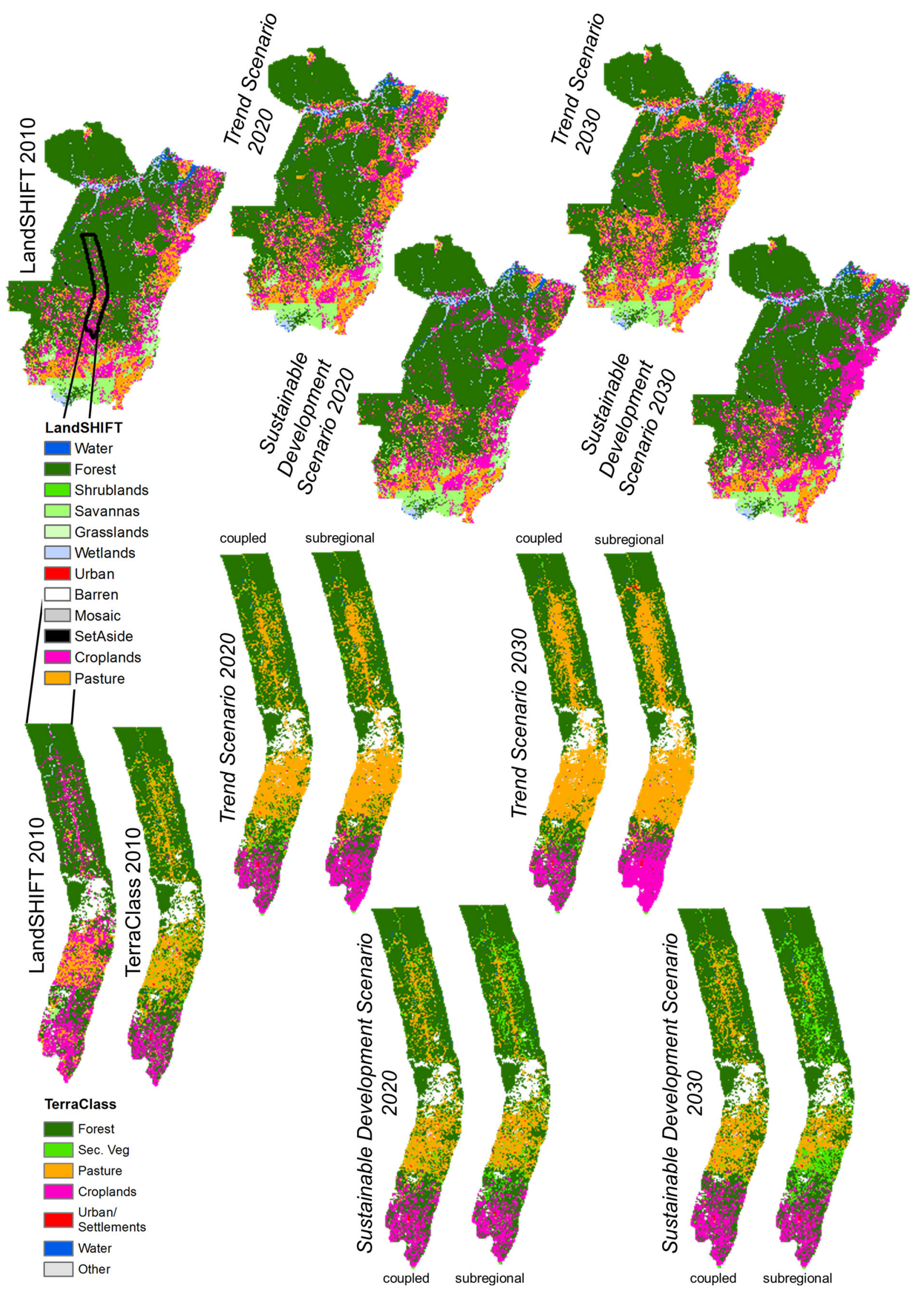


The coupled Trend scenario highlights the BR-163 region to experience further pasture expansion. Cropland expands more in other regions of MT and PA than along the BR-163 corridor, and similarly, urban expansion is not likely to occur along the highway. The subregional quantification of the Trend scenario was similarly dominated by the expansion of pastures along the highway. Additionally, both cropland and urban areas expanded, which led to the highest deforestation rates. These trends portray the recent dynamics along the BR-163, shaped by land-use intensification, expansion of export-oriented crops, and increasing land prices (Richards 2012; Rudorff et al. 2011). However, the latest dynamics within the region, the implementation of land-use policies such as the PPCDAm, and agricultural prices have slowed the expansion of cropland and pasture (Gibbs et al. 2015; Gollnow and Lakes 2014; Macedo et al. 2012)

The Sustainable Development scenario was quantified by adjusting the trend scenario toward global and regional changes in diet, decreasing cattle production, and enforcing spatial policies (e.g., for protected areas, indigenous lands, sustainable use areas, and military areas). The results from the coupled Sustainable Development scenario highlight different land-use change intensities between the BR-163 corridor and the states of MT and PA, although both experienced decreases in pasture and increases in cropland. The change rates for all of MT and PA were double those along the BR-163. The BR-163 region continues to be characterized by pastureland. The subregional quantification resulted in a drastic reduction of pastures with a small increase in cropland. Distinct from the other scenarios, secondary vegetation increased in former pasture areas, especially in PA and between Sinop and Guarantã do Norte (MT). These differences between the two quantification approaches stress the importance of scale for scenario quantification.

On the one hand, the scenario analysis identified the BR163 corridor as one of the regions in MT and PA that is especially prone to further pasture expansion. On the other hand, cropland expansion was more likely in other regions of MT and PA than along the BR-163 corridor and may be a smaller thread to deforestation than increased cattle production. Within the corridor, cropland was more likely to expand in the south of the study region along the BR163, where relief, precipitation, and infrastructure are more favorable. Pasture expansion, in contrast, was determined by infrastructure availability or accessibility and appeared to be indifferent to biophysical determinates (Table S.7). Using this rationale, effectively implementing the Beef Moratorium and completing the CAR combined with intensification efforts can be important for curbing deforestation in the region, next to the notably successful implementation of the Soy Moratorium and the strategies implemented in the PPCDAm.
The variation of deforestation under the different scenarios and quantification approaches stresses the scale dependency and uncertainties involved in spatially explicit scenario analyses. The highest deforestation estimates were calculated for the subregional quantification of the Trend scenarios. To reduce deforestation, it will be critical to find pathways toward more sustainable development at the global, regional, and subregional scales (Aguiar et al. 2016).

\section{Conclusion}

This study provided scenarios of land-use change along the BR-163 highway in the Brazilian Amazon by comparing a multiscale model coupling approach with a conventional subregional scenario quantification. We found large differences between the scenarios and the quantification approaches, which emphasizes the importance of scale and uncertainties in scenario quantification.

We found that combining coarse- and high-resolution landuse data across spatial scales provided high spatial detail at the subregional level while accounting for land-use changes across scales. On the contrary, subregional model quantification may be superior in capturing locally specific dynamics. However, the limited extent of the subregional model could make it prone to overpredicting land-use changes because all changes are restricted to the defined boundaries.

Beyond the above-mentioned considerations, we believe that by applying land-use maps of different resolutions, each adequate for the spatial scales involved, we increased the credibility of the spatially explicit scenarios for the subregional level compared with the results of large-scale scenario models. This is especially true for cases in which high-resolution spatial maps are not available for use as inputs in large-scale models but are available for subsets of the area of interest.

Overall, the scenarios identify the region along the BR163 as likely to experience additional pasture expansion. This underlines the importance of policies to curb deforestation, strengthen the efforts to implement the Beef Moratorium, complete the CAR, alongside the notably successful implementation of the Soy Moratorium and the PPCDAm's environmental monitoring and expansion of the protected areas network.

Acknowledgements This work has been supported by the BrazilianGerman cooperation project "Carbon Sequestration, Biodiversity and Social Structures in Southern Amazonia (CarBioCial, www.carbio cial.de)" and financed by the German Ministry of Research and Education (BMBF, Grant no. 01LL0902). Leticia Hissa acknowledges the CAPES/SWB program for granting a scholarship (1047-13/2). We additionally thank our colleagues Hannes Müller, Philippe Rufin, and Thomas Mönkemeier for their comments and discussions and the 
anonymous reviewers for their comments, which helped to significantly improve an earlier version of the manuscript.

Open Access This article is distributed under the terms of the Creative Commons Attribution 4.0 International License (http://crea tivecommons.org/licenses/by/4.0/), which permits unrestricted use, distribution, and reproduction in any medium, provided you give appropriate credit to the original author(s) and the source, provide a link to the Creative Commons license, and indicate if changes were made.

\section{References}

Agência Nacional de Águas-ANA (2010) Rede de Drenagem. Hidrografia 1:1.000.000 (base digital georreferenciada). http:// hidroweb.ana.gov.br/HidroWeb.asp?TocItem $=4100$. Accessed $21 \mathrm{Feb} 2017$

Aguiar APD de, Câmara G, Escada MIS (2007) Spatial statistical analysis of land-use determinants in the Brazilian Amazonia. exploring intra-regional heterogeneity. Ecol Model 209(2-4):169-188. doi:10.1016/j.ecolmodel.2007.06.019

Aguiar APD de, Vieira ICG, Assis TO, Dalla-Nora EL, Toledo PM, Oliveira Santos-Junior RA, Batistella M, Coelho AS, Savaget EK, Aragão LEOC, Nobre CA, Ometto JPH (2016) Land use change emission scenarios: anticipating a forest transition process in the Brazilian Amazon. Glob Change Biol 22(5):1821-1840. doi:10.1111/gcb.13134

Alcamo J (ed) (2008) Environmental futures. The practice of environmental scenario analysis, 1st ed. Developments in integrated environmental assessment, v. 2. Elsevier, Amsterdam

Alcamo J, Kok K, Busch G, Priess JA, Eickhout B, Rounsevell Mark D A, Rothman DS, Heistermann M (2006) Searching for the Future of Land: Scenarios from the Local to Global Scale. In: Lambin EF, Geist $\mathrm{H}$ (eds) Land-use and land-cover change. Local processes and global impacts. Springer, Berlin, pp 137-155

Alcamo J, Schaldach R, Koch J, Kölking C, Lapola DM, Priess JA (2011) Evaluation of an integrated land use change model including a scenario analysis of land use change for continental Africa. Environ Model Softw 26(8):1017-1027. doi:10.1016/j. envsoft.2011.03.002

Almeida CAd, Pinheiro TF, Barbosa AM, Abreu MR, Lobo FdL, Silva M, Gomes AR, Sadeck LWR, Medeiros LTBd, Neves MF, Silva LdCTd, Tamasauskas PFLF (2009) Metologia para mapeamento de vegetacao secundaria na amazonia legal, Ŝa Jośe dos Campos

Almeida CAd, Coutinho AC, Esquerdo Júlio César, Mora Dalla, Adami M, Venturieri A, Diniz CG, Dessay N, Durieux L, Gomes AR (2016) High spatial resolution land use and land cover mapping of the Brazilian Legal Amazon in 2008 using Landsat5/TM and MODIS data. Acta Amazonica 46:291-302

Arima EY, Richards PD, Walker RT, Caldas M (2011) Statistical confirmation of indirect land use change in the Brazilian Amazon. Environ Res Lett 6:1-7

Arima EY, Walker RT, Perz S, Souza C (2016) Explaining the fragmentation in the Brazilian Amazonian forest. J Land Use Sci 11(3):257-277. doi: 10.1080/1747423X.2015.1027797

Arvor D, Margareth M, Dubreuil V, Bégué A, Shimabukuro YE (2011) Analyzing the agricultural transition in Mato Grosso, Brazil, using satellite-derived indices. Appl Geogr 32(2):702-713

Assis TO, Souza Soler L de, Aguiar APD de, Ometto J (2011) Assessing risk maps of deforestation to the Brazilian Amazon using LuccME framework
Assunção J, Gandour CC, Rocha R, Climate Policy Initiative (2012) Deforestation slowdown in the legal Amazon: prices or policies? CPI working paper. Climate Policy Initiative, Rio de Janeiro

Assunção J, Gandour CC, Rocha R (2013) DETERring deforestation in the Brazilian Amazon: environmental monitoring and law enforcement. climate policy initiative report, PUC-Rio, May

Bondeau A, Smith PC, Zaehle S, Schaphoffs S, Lucht W, Cramer W, Gerten D, Lotze-Campen H, Müller C, Reichstein M, Smith B (2007) Modelling the role of agriculture for the 20th century global terrestrial carbon balance. Global Change Biol 13(3):679-706. doi:10.1111/j.1365-2486.2006.01305.x

Boucher D, Roquemore S, Fitzhugh E (2013) Brazil's success in reducing deforestation. Trop Conserv Sci 6(3):426-445

Brazilian Forest Code, Federal Law 12.727 (2012). http://www. planalto.gov.br/ccivil_03/_Ato2011-2014/2012/Lei/L12727.htm. Accessed 17 Jan 2017

Brown DG, Band LE, Green KO, Irwine EG, Jain A, Lambin EF, Pontius RG Jr, Seto KC, Turner BL, Verburg PH, Graf WL, Bebbington A, Easterling WE, Harden CP, Kelmelis JA, Luers AL, Macdonald GM, Macdowell P, Moser SC, Rain DR, Brierley CL, Cutter SL, Hitzman MW, Kavazanjian E Jr, Maest AS, Maidment DR, Mcmaster R, Miller MM, Montanez IP, Mora CI, Moudgil BM, Nichols CR, Pollack HN, Sandwell DT, Shearer PM, Spiller R, Whitney G (2014) Advancing land change modeling. Opportunities and research requirements. National Academies Press, Washington

Brown-Lima C, Cooney M, Cleary D (2010) An overview of the Brazil-China soybean trade and its strategic implications for conservation. The Nature Conservancy Latin America Region, Brazil. https://www.nature.org/ourinitiatives/regions/southamer ica/brazil/explore/brazil-china-soybean-trade.pdf

Coy M, Klingler M (2010) Pionierfront im brasilianischen Amazonien zwischen alten Problem und neuen Dynamiken. Das Beispiel des "Entwicklungskorridors" Cuiaba (Mato Grosso) Santarem (Para). Insbrucker Jahresberichte 2008-2010:109-129

Dalla-Nora EL, de Aguiar APD, Lapola DM, Woltjer G (2014) Why have land use change models for the Amazon failed to capture the amount of deforestation over the last decade? Land Use Policy 39:403-411. doi:10.1016/j.landusepol.2014.02.004

DeFries RS, Herold M, Verchot L, Macedo MN, Shimabukuro YE (2013) Export-oriented deforestation in Mato Grosso: harbinger or exception for other tropical forests? Philos Trans R Soc B: Biolog Sci 368(1619):20120173. doi:10.1098/rstb.2012.0173

Espindola GM de, Aguiar APD de, Pebesma E, Câmara G, Fonseca L (2012) Agricultural land use dynamics in the Brazilian Amazon based on remote sensing and census data. Appl Geogr 32(2):240-252. doi:10.1016/j.apgeog.2011.04.003

ESRI - Environmental Systems Research Institute (2000) ESRI Data \& Maps - World Cities, Redlands, California, USA

FAO (2002) Tropical livestock units (TLU). http://www.fao.org/ docrep/005/Y4176E/y4176e04.htm. Accessed 19 Jan 2017

FAO (2015) FAOSTAT database collections. Database, Rome

Fearnside PM (2007) Brazil's Cuiaba-Santarem (BR-163) Highway. The environmental cost of paving a soybean corridor through the Amazon. Environ Manag 39(5):601-614. doi:10.1007/s00267006-0149-2

Friedl MA, Sulla-Menashe D, Tan B, Schneider A, Ramankutty N, Sibley A, Huang X (2010) MODIS Collection five global land cover: algorithm refinements and characterization of new datasets. Remote Sens Environ 114(1):168-182. doi:10.1016/j. rse.2009.08.016

Fritz S, See L, McCallum I, Schill C, Obersteiner M, van der Velde M, Boettcher H, Havlík P, Achard F (2011) Highlighting continued uncertainty in global land cover maps for the user community. Environ Res Lett 6(4):44005 
Gibbs HK, Rausch L, Munger J, Schelly I, Morton DC, Noojipady P, Soares-Filho BS, Barreto L, Micol N, Walker NF (2015) Brazil's soy moratorium. Science 347(6220):377. doi:10.1126/science. aaa0181

Gil J, Siebold M, Berger T (2015) Adoption and development of integrated crop-livestock-forestry systems in Mato Grosso, Brazil. Agric Ecosyst Environ 199:394-406. doi:10.1016/j. agee.2014.10.008

GLCF (2014) MODIS land cover. MCD12Q1. http://glcf.umd.edu/ data/lc/. Accessed 19 Jan 2017

Godar J, Suavet C, Gardner TA, Dawkins E, Meyfroidt P (2016) Balancing detail and scale in assessing transparency to improve the governance of agricultural commodity supply chains. Environ Res Lett 11(3):35015

Gollnow F (2015) alucR. allocation of land use change in R. https:// github.com/fg-code/alucR_v01

Gollnow F, Lakes T (2014) Policy change, land use, and agriculture: the case of soy production and cattle ranching in Brazil, 2001-2012. Appl Geogr 55:203-211

Herold M, Mayaux P, Woodcock CE, Baccini A, Schmullius C (2008) Some challenges in global land cover mapping: an assessment of agreement and accuracy in existing $1 \mathrm{~km}$ datasets. Earth Obs Terr Biodivers Ecosyst Spec Issue 112(5):2538-2556. doi:10. 1016/j.rse.2007.11.013

IBGE (2010a) Censo Demográfico. http://www2.sidra.ibge.gov.br/ $\mathrm{bda} / \mathrm{acervo} / \mathrm{acervo}$. $\mathrm{asp} ? \mathrm{e}=\mathrm{v} \& \mathrm{t}=195 \& \mathrm{p}=\mathrm{CD} \& \mathrm{z}=\mathrm{t} \& \mathrm{o}=3$. Accessed $21 \mathrm{Feb} 2017$

IBGE (2010b) ST_RODOVIA. Shape. ftp://geoftp.ibge.gov.br/cartas_ e_mapas/bases_cartograficas_continuas/bcim/versao2010/bcim_ v3.04_dados/shapefile. Accessed 21 Feb 2017

IBGE (2013) Pesquisa Pecuária Municipal. http://www2.sidra.ibge. gov.br/bda/tabela/listabl.asp?c=1612\&z=t\&o=3. Accessed 21 Feb 2017

IBGE (2015) Sistema IBGE de Recuperacao Automatica-SIDRA. http://www.sidra.ibge.gov.br/

IBGE (2016) Produção Agrícola Municipal. http://www2.sidra.ibge. gov.br/bda/tabela/listabl.asp?c $=1612 \& \mathrm{z}=\mathrm{t} \& \mathrm{o}=3$. Accessed 21 Feb 2017

INPE (2015) projecto terraclass. http://www.inpe.br/cra/projetos_ pesquisas/dados_terraclass.php. Accessed 23 Apr 2015

INPE (2016) projecto prodes. Monitoramento da floresta Amazônica Brasileira por satélite. http://www.obt.inpe.br/prodes/. Accessed 2 Dec 2016

Kaptué Tchuenté AT, Roujean J-L, de Jong SM (2011) Comparison and relative quality assessment of the GLC2000, GLOBCOVER, MODIS and ECOCLIMAP land cover data sets at the African continental scale. Int J Appl Earth Obs Geoinf 13(2):207-219. doi:10.1016/j.jag.2010.11.005

Lapola DM, Schaldach R, Alcamo J, Bondeau A, Koch J, Koelking C, Priess JA (2010) Indirect land-use changes can overcome carbon savings from biofuels in Brazil. Proc Natl Acad Sci 107(8):3388-3393. doi:10.1073/pnas.0907318107

Lapola DM, Schaldach R, Alcamo J, Bondeau A, Msangi S, Priess JA, Silvestrini R, Soares-Filho BS (2011) Impacts of climate change and the end of deforestation on land use in the Brazilian Legal Amazon. Earth Interact 15(16):1-29. doi:10.1175/2010EI333.1

Lapola DM, Martinelli LA, Peres CA, Ometto JPHB, Ferreira ME, Nobre CA, Aguiar APDd, Bustamante MMC, Cardoso MF, Costa MH et al (2014) Pervasive transition of the Brazilian landuse system. Nat Clim Change 4(1):27-35

Laurance WF, Cochrane MA, Bergen S, Fearnside PM, Delamônica P, Barber C, D'Angelo S, Fernandes T (2001) The future of the Brazilian Amazon. Science 291(5503):438-439. doi:10.1126/ science.291.5503.438

Lehner B, Grill G (2013) Global river hydrography and network routing. Baseline data and new approaches to study the world's large river systems. Hydrol Process 27(15):2171-2186. doi:10. 1002/hyp. 9740

Macedo MN, DeFries RS, Morton DC, Stickler C, Galford GL, Shimabukuro YE (2012) Decoupling of deforestation and soy production in the southern Amazon during the late 2000s. Proc Natl Acad Sci 109(4):1341-1346. doi:10.1073/pnas.1111374109

Maeda EE, de Almeida CM, de Ximenes AC, Formaggio AR, Shimabukuro YE, Pellikka P (2011) Dynamic modeling of forest conversion: simulation of past and future scenarios of rural activities expansion in the fringes of the Xingu National Park, Brazilian Amazon. Int J Appl Earth Obs Geoinf 13(3):435-446. doi:10.1016/j.jag.2010.09.008

McLeod AI, Xu C (2015) bestglm: best subset GLM. https://cran.rproject.org/web/packages/bestglm/vignettes/bestglm.pdf. Accessed 2015

Meyfroidt P, Lambin EF, Erb K-H, Hertel TW (2013) Globalization of land use: distant drivers of land change and geographic displacement of land use. Curr Opin Environ Sustain 5:438-444. doi:10.1016/j.cosust.2013.04.003

MMA (2013) Plano de ação para Prevenção e Controle do Desmatamento na Amazonia legal (PPCDAm). $3^{\text {a }}$ Fase (2012-2015) Pelo uso sustentável e conservação da floresta

MMA (2015) Download de dados geográphicos. http://mapas.mma. gov.br/i3geo/datadownload.htm. Accessed 19 Jan 2017

Moreira E (2009) Dynamic coupling of multiscale land change models. $\mathrm{PhD}$

Moreira E, Aguiar APD de, Costa S, Câmara G (2008) Spatial relations across scales in land change models. In: Proceedings of the X Brazilian symposium on GeoInformatics, pp 95-107

Müller H, Griffiths P, Hostert P (2016) Long-term deforestation dynamics in the Brazilian Amazon-uncovering historic frontier development along the Cuiabá-Santarém highway. Int J Appl Earth Obs Geoinf 44:61-69

NASA (2015) Tropical rainfall measuring mission (TRMM). http:// disc.sci.gsfc.nasa.gov/precipitation. Accessed 19 Jan 2017

Oliveira LJC, Costa MH, Soares-Filho BS, Coe MT (2013) Largescale expansion of agriculture in Amazonia may be a no-win scenario. Environ Res Lett 8(2):24021. doi:10.1088/1748-9326/ $8 / 2 / 024021$

Richards PD (2012) Indirect land use change and the future of the amazon. $\mathrm{PhD}$, Michigan State University

Richards PD, Walker RT, Arima EY (2014) Spatially complex land change: the indirect effect of Brazil's agricultural sector on land use in Amazonia. Glob Environ Change 29:1-9. doi:10.1016/j. gloenvcha.2014.06.011

Rosa IM, Purves D, Souza C, Ewers RM (2013) Predictive modelling of contagious deforestation in the Brazilian Amazon. PLoS One 8(10):e77231. doi:10.1371/journal.pone.0077231

Rosa IM, Ahmed SE, Ewers RM (2014) The transparency, reliability and utility of tropical rainforest land-use and land-cover change models. Glob Change Biol 20(6):1707-1722. doi:10.1111/gcb. 12523

Rudorff BFT, Adami M, Aguiar DA, Moreira MA, Mello MP, Fabiani L, Amaral DF, Pires BM (2011) The soy moratorium in the Amazon biome monitored by remote sensing images. Remote Sens 3(12):185-202. doi:10.3390/rs3010185

Schaldach R, Alcamo J, Koch J, Kölking C, Lapola DM, Schuengel J, Priess JA (2011) An integrated approach to modelling land-use change on continental and global scales. Environ Model Softw 26:1041-1051. doi:10.1016/j.envsoft.2011.02.013

Soares-Filho BS, Assunção RM, Pantuzzo AE (2001) Modeling the spatial transition probabilities of landscape dynamics in an Amazonian Colonization Frontier. BioScience 51(12):1059-1067. doi:10.1641/0006-3568(2001)051[1059:MTSTPO]2.0.CO;2. https:// academic.oup.com/bioscience/article/51/12/1059/224009/Modelingthe-Spatial-Transition-Probabilities-of 
Soares-Filho BS, Alencar A, Nepstad DC, Cerqueira GC, Vera Diaz MdC, Rivero S, Solórzano L, Voll E (2004) Simulating the response of land-cover changes to road paving and governance along a major Amazon highway: the Santarém-Cuiabá corridor. Glob Change Biol 10(5):745-764. doi:10.1111/j.1529-8817. 2003.00769.x

Soares-Filho BS, Nepstad DC, Curran LM, Cerqueira GC, Garcia RA, Ramos CA, Voll E, McDonald A, Lefebvre P, Schlesinger P (2006) Modelling conservation in the Amazon basin. Nature 440(7083):520-523. doi:10.1038/nature04389

Soares-Filho BS, Alencar A, Carneiro A, Coe M, Costa W, Macedo MN, Rajão R, Rodrigues H (2014) Cracking Brazil's forest code. Science 344(6182):363-364. doi:10.1126/science.1246663

Turner BL, Lambin EF, Reenberg A (2007) The emergence of land change science for global environmental change and sustainability. Proc Natl Acad Sci 104(52):20666-20671. doi:10.1073/ pnas.0704119104

United States Geological Survey (USGS) (2000) Shuttle radar topography mission (SRTM). https://lta.cr.usgs.gov/SRTM. Accessed 19 Jan 2017

Verburg PH, Koning GHJd, Kok K, Veldkamp A, Bouma J (1999) A spatial explicit allocation procedure for modelling the pattern of land use change based upon actual land use. Ecol Model 116(1):45-61. doi:10.1016/S0304-3800(98)00156-2

Verburg PH, Overmars KP, Huigen MG, de Groot WT, Veldkamp A (2006) Analysis of the effects of land use change on protected areas in the Philippines. Appl Geogr 26(2):153-173. doi:10. 1016/j.apgeog.2005.11.005

Verburg R, Filho SR, Lindoso D, Debortoli N, Litre G, Bursztyn M (2014) The impact of commodity price and conservation policy scenarios on deforestation and agricultural land use in a frontier area within the Amazon. Land Use Policy 37:14-26. doi:10. 1016/j.landusepol.2012.10.003

Wassenaar T, Gerber P, Verburg PH, Rounsevell MDA, Ibrahim M, Steinfeld H (2007) Projecting land use changes in the Neotropics. The geography of pasture expansion into forest. Glob Environ Change Human Policy Dimens 17(1):86-104. doi:10. 1016/j.gloenvcha.2006.03.007

Wint W, Robinson T (2007) Gridded livestock of the world 2007. Food and Agriculture Organization of the United Nations (FAO), Rome

Zoneamento Ecológico-Econômico da Rodovia BR-163 (ZEE) (2008) Military Areas (Shapefile). Zoneamento Ecológico-Econômico da Rodovia BR-163 